\title{
Prey Preference in Genlisea Small Crustaceans, Not Protozoa
}

Douglas W. DARnowsKi • Indiana University Southeast • 4201 Grant Line Road • New Albany, Indiana $47150 \cdot$ USA • ddarnows@ius.edu SARAH FrITZ •Washington College • 300 WashingtonAvenue • Chestertown, Maryland $21620 \bullet$ USA

Keywords: cultivation: carnivory: amphipods, copepods, protozoans, G enlisea.

Introduction

It has been reported that $\mathrm{G}$ enlisea (seeBack Cover) is a plant which special izes in trapping ciliate protozoa, such as B lepharisma, which it has chemotactical ly attracted, and it was claimed further to bethe first such example known (Barthlott et al. 1998). Those authors used both SouthA merican (G. aurea, G. violacea) and African (G. margaretae) species for their work, and they found or were able to cite evidence for prey being attracted by means of released chemicals, for the release of digestive enzymes, and the absorption and translocation of radioactive ${ }^{35} \mathrm{~S}$ (Barthlott et al. 1998).

However, a number of questions have been rai sed about this claim (Plachno et al . 2005a). First, the prey offered to the plants in the experiments described above may bevery different fromtheprey which these plants would encounter in nature, making the identification of $\mathrm{G}$ enlisea as special izing in trapping protozoa suspect. Natural ly occurning organisms which might serve as prey might also include small crustaceans and other small animals such as water bears.

Second, while the mechanism of the trap was at one point proposed to involve flow of water, and which might be ideal for capture of protozoa (Meyers-Rice 1994), it was subsequently found to have no water flow involved (Adamec 2003). Instead, the mechani sm seems to invol ve both inwardpointing hairs and mucilage (Stuidnicka 2003a, 2003b) which help to point potential prey into the digestive bul b of the trap and to prevent their escape. Given the presence of the mucilage and hairs, these traps may be difficult for smal protozoa to enter and may be adapted more for catching larger, stronger, more nutrient-rich prey like small crustaceans which are better equi pped to enter the traps.

To test the prey spectrum of G enlisea, experiments were performed using G. filiformis from South America; 1) to determine which types of prey organisms were preferentially trapped when a mixture of prey was presented to the plants and 2) to determine whether the released chemoattractants affected ciliate protozoa, as suggested by Barthlottet al . (1998).

\section{Materials and Methods}

G enlisea filiformis plants fromold tissue cultures, originally made on 1/5-strength tissue culture media (Darnowski 2004), low in nutrients were used, after hardening off on soil (sand-peat mixture). This ensured that plants were not well-stocked with nutrients and thus prevented high nutrient levels from reducing the drive for carnivory.

For the first type of experiment, repeated thrice, plants were placed in a dish with their white trapping leaves in filtered pond water. Then, potential prey were added as follows: 3 drops of a culture of B lepharisma sp., a ciliate protozoan used by Barthlott et al. (1998; provided hundreds of organisms); 3 drops of a culture of Euglena acus, a flagellate protozoan (hundreds of prey provided); 4 drops of a culture of H ypsibius sp., a waterbear (animal phylum, size of a typical 10um protozoan; dozens to hundreds provided); 3 drops of a culture of copepods (C yclops sp.), a small crustacean (about 10 provided); 3 drops of a culture of amphipods (G ammarus sp.), a small crustacean about 10 times larger than Cyclops (about 5 provided). Organisms were left with the plants for 1 week, and then trapping was scored using a dissecting microscope

For the second type of experiment, bactoagar cubes approximately $0.5 \mathrm{~cm}(0.2 \mathrm{in})$ on a side were placed either in pond water (control) or under the trapping leaves of $\mathrm{G}$. filiformis growing in soil for 1 
week to allow absorption of chemicals from the local environments. Chemoattractants from $G$. filiformis should have been absorbed during this time by the agar cubes. These were then placed in the center of $100 \mathrm{~mm}$ plastic petri dishes in filtered pond water, and prey were added as noted above except for amphi pods, since these were never trapped in the first type of experiment After about a half-hour for equilibration and diffusion of chemoattractants, the position of prey of each type was found for about 5 individuals found by randomly selecting fields of view around the dish under a dissecting microscope.

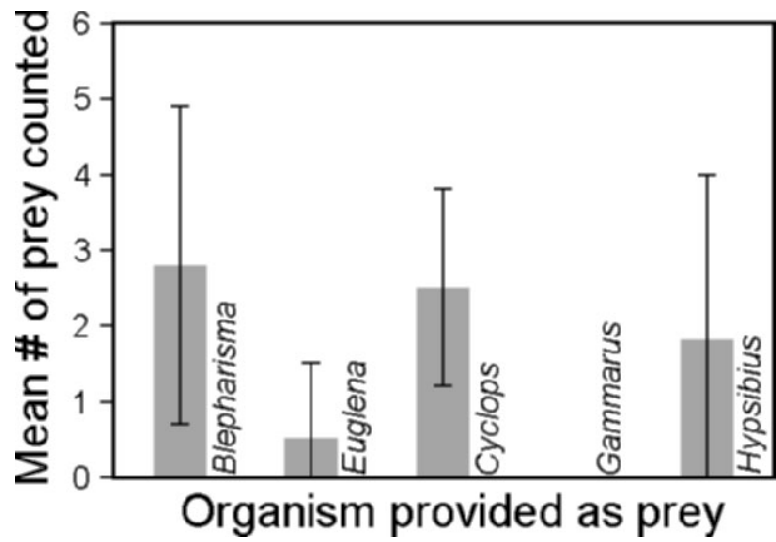

Figure 1: Prey counted in Genlisea filiformis traps. Blepharisma: 2.8 \pm 2.1 , Euglena: 0.5 \pm 1 , Cyclops: $2.5 \pm 1.3$, Gammarus: 0.0, Hypsibius: $1.8+2.2$.

Position was recorded relative to the agar cube The mean distance from the bl ock was determined for each prey item and the experiment was repeated threetimes. Then, the overall mean and the standard error of the mean were calculated for each prey item across the three repetitions.

\section{Results}

As can be seen from Figure 1, the G. filiformis plants never trapped amphipods, and they trapped about the same number of copepods as other prey, all of the other prey being much smaller than the copepods.

Figure 2 shows theresults of the experiment with chemoattractants absorbed by agar bl ocks. The data are graphed with $2.5 \mathrm{~cm}$ subtracted from each distance. This was done to emphasize whether position was random or not, since $2.5 \mathrm{~cm}$ is the average distance from the center of the dish to the edge. If prey were distributed away from the agar block in no particular position, a mean distance of $2.5 \mathrm{~cm}$ would be expected. Negative numbers indicate closer placement towards the agar block, demonstrating attraction by the block/chemicals diffusing from it, and positive numbers indicate movement away from the block, i.e. repul sion by released chemicals. The distance from the center of the dish at which a circle can be drawn to evenly divide the area of the dish into two parts is at about $3.6 \mathrm{~cm}$, based on simple geometric considerations. However, given that the dish has a reflectiveedge at the outside of the dish but not at the center, and such an edgemight well deter negatively phototactic prey, theexperimenter has chosen the midpoint of the radius of the dish, $2.5 \mathrm{~cm}$, instead. Even if the data were recentered around the $3.6 \mathrm{~cm}$ line, the basic conclusion of this paper would not be changed.

\section{Discussion}

From the data presented, clearly prey preference in $\mathrm{G}$ enlisea is for small crustaceans, not protozoa. Figure 1 shows that $G$. filifor mis trapped relatively few prey of any type, but the prey counted most frequently werethe protozoan B lepharisma and the copepod C yclops. However, the protozoan prey were presented with an abundance of approximately 10 times that of the copepods. Therefore, the plants trapped a much higher percentage of the copepods than any other type of prey. This tends to contradict the cond usions of Barthlott et al. (1998) that $G$ enlisea specializes in trapping protozoa.

Further, from Figure2, B lepharisma seems to be neither attracted nor repul sed by either control or G enlisea-blocks of agar. Other prey, including copepods, stayed further than $2.5 \mathrm{~cm}$ from the blocks for controls but came cl oser than $2.5 \mathrm{~cm}$ to the $\mathrm{G}$ enl isea-bl ock. This may show that chemoat- 
tractants had been absorbed by the blocks and that some prey were indeed attracted by them, including the flagel late protozoan E ugl ena acus.

Taken together, these two experiments suggest that $\mathrm{G}$ enlisea does emit water-soluble chemoattractants which do attract a range of prey, both protozoa and animals. Further, proportionally more copepods were trapped than protozoa, and each copepod contains far more resources than each protozoan. Thus, the conclusion of Barthlott et al. (1998) that $G$ enlisea special izes in trapping protozoa is probably incorrect.

This study does not address issues of the differential stability of the remains of different prey. Certainly crustacean prey with their indigestible chitinous exoskeletons would leave longer-lasting traces than easily-digested protozoa and might be overrepresented in the data here. However, given that crustaceans are generally much larger than protozoa and providemuch morenutrients per prey caught, the data shown here do contradict the previous assertion that $G$ enlisea specializes in protozoa.

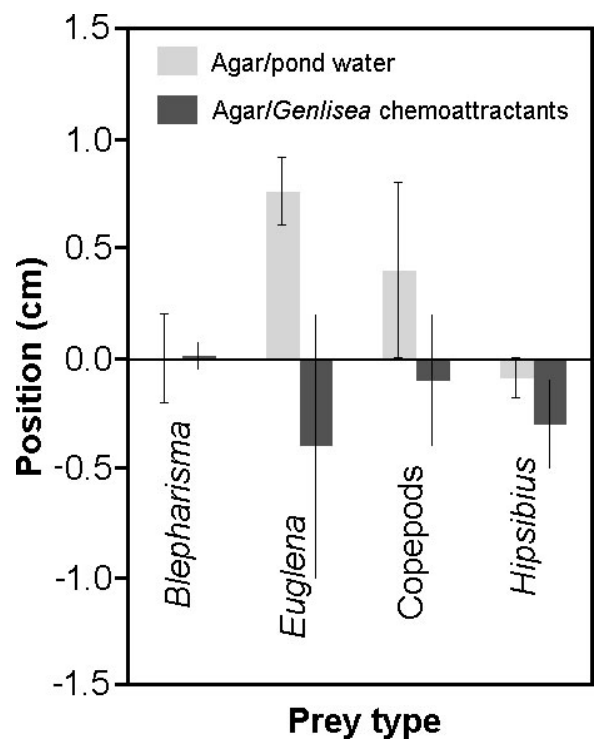

Figure 2: Distances of prey, minus $2.5 \mathrm{~cm}$, from the Genlisea or agar block bait.

\section{References:}

Adamec, L. 2003. Zero water flows in the carnivorous genus G enlisea. Camiv. PI. Newslett 32: 46-48. Barthl ott, W., Porembski, S., Fischer, E., and Gemmel, B. 1998. First protozoatrapping plant found. Nature 392: 447.

Darnowski, D.W. 2004. How to grow a ridiculously large number of sundews. Camiv. PI. Newslett. 33: 90-94.

Meyers-Rice, B.A. 1994. AreG enlisea traps active? A crudecalculation. Carniv. PI. Newslett 23: 40-42. Plachno, B.J., Adamus, K., Faber, J., and Kozlowski, J. 2005a. Feeding behavior of carnivorous G enlisea plants in thelaboratory. Acta. Bot. Gall. 152:159-164.

Plachno, B.J., Faber, J., and J ankun, A. 2005b. Cuticular discontinuities in glandular hairs of $\mathrm{G}$ enlisea St.-Hil. in relation to their functions. Acta Bot. Gall. 152:125-130.

Studnicka, M. 2003a. Genlisea traps--a new piece of knowledge. Carniv. PI. Newslett 32: 36-39. Studnicka, M. 2003b. Further problem in G enlisea trap untangled? Carniv. PI. Newslett. 32: 4-45.

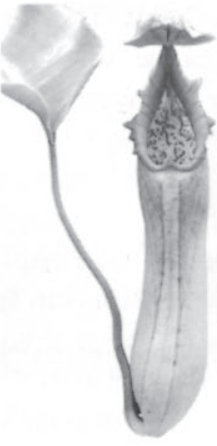

\section{CASCADE CARNIVORES Carnivorous Plant Nursery}

- Drosophyllum lusitanicum

- Yes, we ship Dewy Pine plants - live delivery guarantee

- Nepenthes

- highland species are our specialty

- Drosera, Pinguicula, Utricularia, Byblis, Heliamphora, VFTs and more 


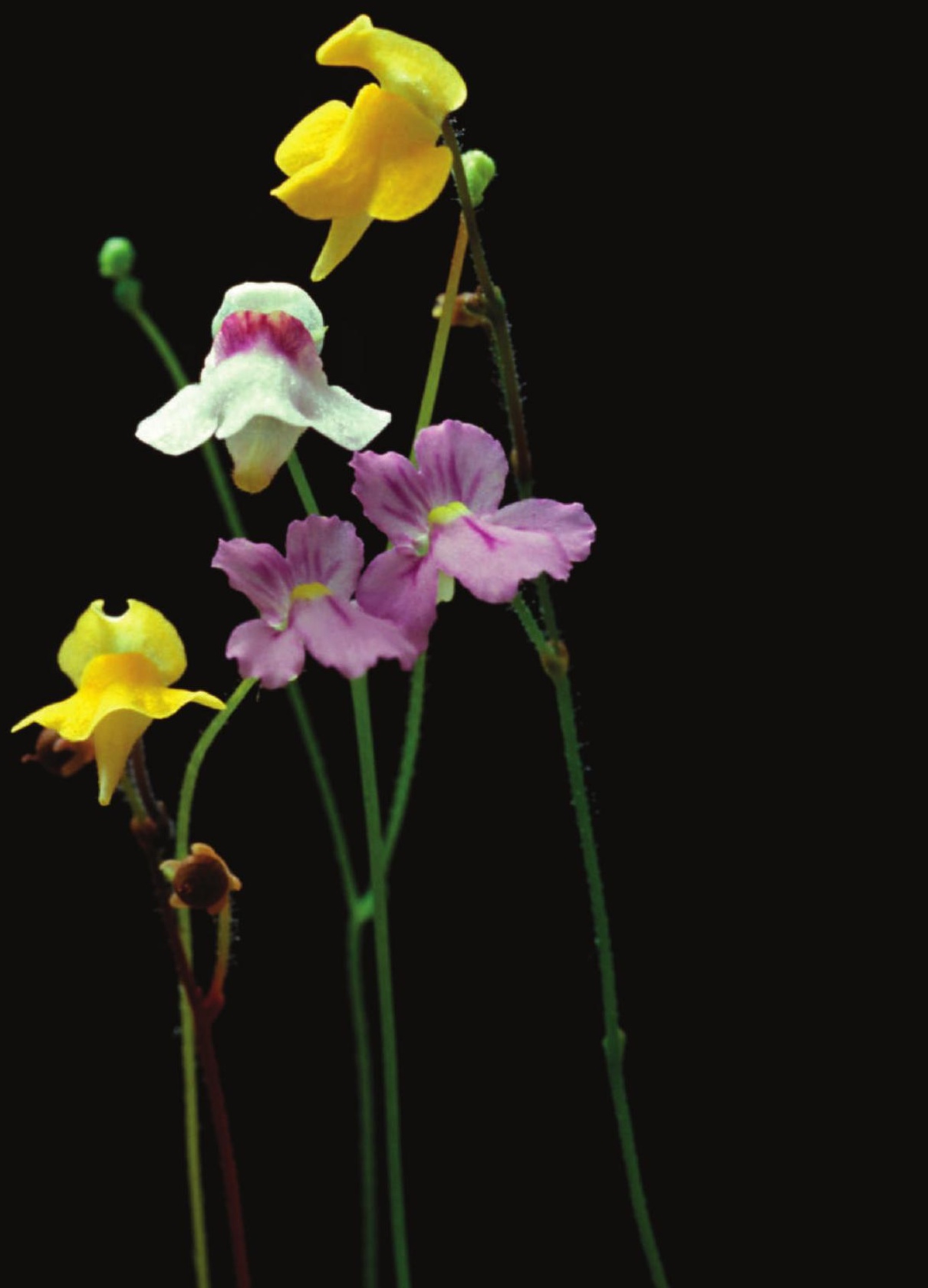




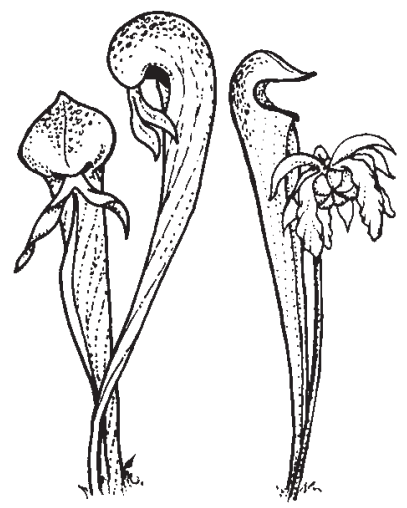

\section{CARNIVOROUS \\ PLANT \\ NEWSLETTER}

Journal of the International

Carnivorous Plant Society

www.carnivorousplants.org

Volume 39, Number 4 December 2010

\section{Front Cover: The Australian Pimpernel Sundew (Drosera glanduligera) in Western Australia. Photo by Barry Rice. Article on page 101.}

\section{Back Cover: A Genlisea bouquet of G. pygmaea (yellow), G. hispidula (lilac), G. violacea (purplish). Photo by Barry Rice. Article on page 114.}

Carnivorous Plant N ewsletter is dedicated to spreading knowledge and news related to carnivorous plants. Reader contributions are essential for this mission to be successful. Do not hesitate to contact the editors with information about your plants, conservation projects, field trips, or noteworthy events. A dvertisers should contact the editors. Views expressed in this publication are those of the authors, not the editorial staff.

All correspondence regarding dues, address changes and missing issues should be sent to the Membership Coordinator at the ICPS. Do not send such correspondence to the editors. Checks for subscriptions should be made to the ICPS in US funds. Dues for 2011 are \$35 for the first year of membership; renewals are \$30 per year.
ICPS, Inc.
PM B 322
1564-A Fitzgerald Drive
Pinole, CA 94564-2229, USA
icps@carnivorousplants.org

$\begin{array}{ll}\text { President } & \text { M ichael Baldwin, michael@ carnivorousplants.org } \\ \text { Vice President } & \text { Marcel van den B roek, marcel@ carnivorousplants.org } \\ \text { Secretary } & \text { Cindy Slezak, cindy@ carnivorousplants.org } \\ \text { Treasurer } & \text { Richard M yers, richard@ carnivorousplants.org } \\ \text { B oard M ember } & \text { B ob Ziemer, bob@ carnivorousplants.org } \\ \text { B oard M ember } & \text { Jan Schlauer, jan@ carnivorousplants.org } \\ \text { B oard M ember } & \text { B Bian B arnes, Conservation Director, brian@ carnivorousplants.org } \\ \text { Seed Bank M anager } & \text { John B rittnacher, john@ carnivorousplants.org (see seed bank ad in this issue) }\end{array}$

Editors:

M anaging Editor Bob Ziemer, bob@carnivorousplants.org

Science Editor Jan Schlauer, jan@ carnivorousplants.org

Science Editor $\quad$ Fernando Rivadavia, fernando@ carnivorousplants.org

Editor

Barry Rice, barry@ carnivorousplants.org

Date of effective publication of the September 2010 issue of Carnivorous Plant N ewsletter: 1 September 2010.

The ICPS is the International Cultivar Registration A uthority (ICRA) for the names of cultivated carnivorous plants according to the International Code of N omenclature for Cultivated Plants. Send relevant correspondence to the ICPS, Inc.

PU BLISHER: ICPS, Inc., Pinole, California. Published quarterly with one volume annually. Printed by A llen Press, Inc., 810 E. 10th Street, L awrence, KS 66044. L ogo and masthead art: Paul M ilauskas.

Dues for 2011 are $\$ 35$ for the first year of membership; renewals are $\$ 30$ per year.

c 2010 Carnivorous Plant N ewsletter. All rights reserved. ISSN \#0190-9215 